\title{
Numerical phenetic and phylogenetic relationships in silico among brown seaweeds (Phaeophyceae) from Gunungkidul, Yogyakarta, Indonesia
}

\author{
AJENG MEIDYA NINGRUM, ABDUL RAZAQ CHASANI \\ Faculty of Biology, Universitas Gadjah Mada. J1. Teknika Selatan, Sekip Utara, Sleman 55281, Yogyakarta, Indonesia. \\ Tel./fax.: +62-274-580839, "email: ar.chasani@ugm.ac.id
}

Manuscript received: 26 March 2021. Revision accepted: 6 May 2021

\begin{abstract}
Ningrum AM, Chasani AR. 2021. Numerical phenetic and phylogenetic relationships in silico among brown seaweeds (Phaeophyceae) from Gunungkidul, Yogyakarta, Indonesia. Biodiversitas 22: 3057-3064. Human activities such as industrial and tourism development on coastal areas in Indonesia are dreaded to affect seaweed diversity, including brown seaweeds (Phaeophyceae). Though study on brown seaweeds diversity has been done quite a lot, there is no record of analysis of phenetic and phylogenetic relationships among brown seaweeds. Hence, this study aims to determine the phenetic and phylogenetic relationships in silico among brown seaweeds and define characters that play a role in the clustering of brown seaweeds from Gunungkidul, Yogyakarta, Indonesia. Exploration was done using purposive sampling method. Numerical phenetic analysis was generated using MVSP 3.1. Further clustering method was implemented to identify phenetic relationships The PCA method was used to reveal morphological, anatomical, and biochemical characters that determine the clustering pattern. The phylogenetic relationships in silico analysis were conducted using $r b c \mathrm{~L}$ genes from NCBI GenBank database. All multiple sequences were aligned using ClustalW and phylogram reconstruction was performed using Neighbor-Joining (NJ) method in MEGA 7.0. Our study showed that both the analyses, i.e., numerical phenetic and phylogenetic relationships in silico resulted in two main clusters although the species composition of the clusters was slightly different. The PCA analysis indicated that the morphological characters i.e. blade shape, phylloid shape, thalli height, length of the main axis, and the water bladder shape play an important role in the clustering of brown seaweeds species.
\end{abstract}

Keywords: Clustering, Dictyotales, Ectocarpales, Fucales, Ordination, PCA, UPGMA

\section{INTRODUCTION}

Brown seaweeds (Phaeophyceae) are benthic marine macroalgae that are distributed abundantly in the intertidal and sub-littoral zones of marine waters and can be found between the tropics and arctic region. As benthic thallophytes, brown seaweeds grow attached to the substrate to often establish on reef flats (Kadi 2005). According to Chasani and Suyono (2020), brown seaweeds are mostly found between shallow areas up to $200 \mathrm{~m}$ below sea level. The wide distribution of these seaweeds allows a high species diversity. Also, brown seaweeds are the main element of the vegetation in rocky shores, mainly dominated by the order Fucales (Sahoo and Seckbach 2015).

The class of brown seaweeds consists of 16 orders, 54 families with 285 genera, and about 1800 species worldwide (Silberferd et al. 2014). The main character that distinguishes brown seaweeds from the rest of seaweeds lies in their thalli color. Brown seaweeds have a variation in thalli color from yellow to dark brown due to the characteristic pigment content of fucoxanthin, chlorophyll a, chlorophyll $\mathrm{c}$, and $\beta$-carotene produces a brownish yellow color on the thalli. In addition, the genus Sargassum has air bladder, which is one of the distinguishing characters of green and red seaweeds (Karleskint 2010).
Brown seaweeds have macroscopic immobile and multicellular thalli with a variety of shapes. Their morphology are dominated by the leafy thalli shape which has holdfast, stipe, and blade parts as in Sargassum spp. and Turbinaria spp. However, some species also have variety of thalli morphology from filament-shaped, cylindrical, or another complex shape with indistinguishable parts of holdfast, stipe, and blade structures (Draisma et al. 2001). The reproductive organs can be either unilocular (one cell) or plurilocular (many cells). Reproduction can be asexual or sexual, i.e. isogamy, anisogamy, or oogamy. Their life cycle generally involves the diploid (asexual) and the haploid (sexual) generation and both these generations live freely in nature and have the same or different forms (Smith 1951).

The variety of morphological characters found in brown seaweeds is the basis for phenotypic markers, to distinguish certain species. Environmental conditions and geographic distribution easily influence phenotypic characters, so identification work based on solely morphological characters is complicated. Consequently, a molecular approach is needed to support the identification work. Genes from three genetic compartments (nucleus, plastid, and mitochondrion) have recently been utilized for phylogenetic reconstruction and have also provided useful information for taxonomic study (Zhang et al. 2013). 
Recently, many studies have focused on species diversity of brown seaweeds in Indonesia. However, there is no study covering the relationships among brown algae based on numerical phenetic and phylogenetic analysis. The numerical phenetic relationships can be detected through phenograms constructed by morphological, anatomical, and biochemical characters while determination of the phylogenetic relationships can be done through phylogram constructed using molecular data in silico (Soltis et al. 2012). The present study explores species diversity and the determination of phenetic and phylogenetic relationships to define characters playing key roles in clustering brown seaweeds from Gunungkidul, Yogyakarta, Indonesia.

\section{MATERIALS AND METHODS}

\section{Study sites}

Samples were collected from September 2019 to February 2020, from six locations (Figure 1), i.e. Porok, Sepanjang, Drini, Sarangan, Krakal, and Wediombo Southern coastal areas of Gunungkidul District, Yogyakarta, Indonesia. Collections were made by hand- picking during low tide per $15^{\text {th }}$ of the Lunar calendar, regardless of sex or life-cycle stage. Collections were preserved temporarily in specimen box and labeled with collection numbers, date of collection, and location. Identification of samples and phenetic-phylogenetic relationship analysis was carried out from February to June 2020 in Plant Systematics Laboratory at Faculty of Biology, Universitas Gadjah Mada, Yogyakarta, Indonesia.

\section{Procedures}

Sample collection and identification

Brown seaweed sample collection was done by purposive sampling method. Samples were identified with standard references (Dawes 1998; Abbott and Dawson 1987; Littler and Littler 2003; Readdie et al. 2006), compared to the seaweeds herbarium collections in the Plant Systematics Laboratory, Faculty of Biology, Universitas Gadjah Mada and also with expert help. www.algabase.org was consulted for nomenclature, classification, and verification of identified samples. A list of the identified brown seaweeds from Gunungkidul, Yogyakarta, Indonesia is presented in Table 1.

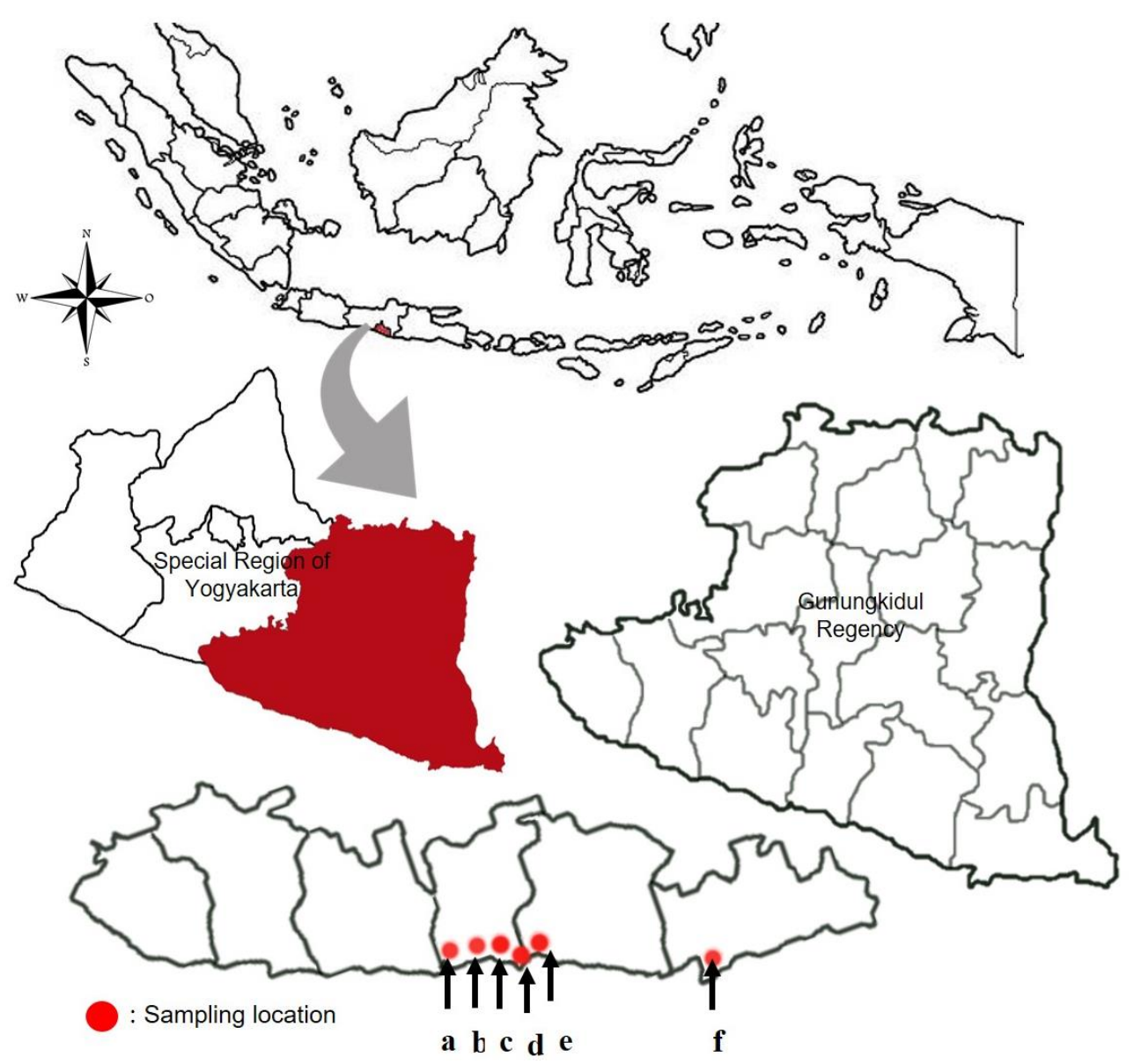

Figure 1. Distribution of sampling sites in Southern coast of Gunungkidul District, Yogyakarta, Indonesia: a. Porok, b. Sepanjang, c. Drini, d. Sarangan, e. Krakal, and f. Wediombo 
Table 1. Brown seaweeds from Gunungkidul, Yogyakarta, Indonesia

\begin{tabular}{llll}
\hline \multicolumn{1}{c}{ Class } & \multicolumn{1}{c}{ Order } & \multicolumn{1}{c}{ Family } & \multicolumn{1}{c}{ Species } \\
\hline Phaeophyceae & Ectocarpales & Corynophlaceae & Cylindrocarpus rugosus Okamura \\
& Punctariaceae & Hydroclathrus clathratus (C.Agardh) M.Howe \\
& Dictyotales & Dictyotaceae & Padina minor Yamada \\
& Fucales & Sargassaceae & Sargassum crassifolium J.Agardh \\
& & $\begin{array}{l}\text { Sargassum cristaefolium } \text { C.Agardh } \\
\text { Sargassum hemiphyllum (Turner) C.Agardh }\end{array}$ \\
& & Sargassum odontocarpum Sonder \\
& & Sargassum oligocystum Montagne \\
& & Sargassum polycystum C.Agardh \\
& & Turbinaria conoides (J.Agardh) Kützing \\
& & Turbinaria ornata (Turner) J.Agardh \\
\hline
\end{tabular}

\section{Morphology-anatomy observation}

Anatomical observation is needed to recognize the cell layer on brown seaweed thallus for each species. Small and thin thalli, which were difficult to be dissected, were put on glass slide and water medium covered with cover glass, while bigger thalli were directly dissected and observed under the microscope connected to an opti-lab.

\section{Pigment analysis}

Pigment analysis of brown seaweeds was performed using Thin Layer Chromatography (TLC) method. Firstly, the samples were oven-dried at a temperature of $40^{\circ}-50^{\circ} \mathrm{C}$. Around 2-5 g dried sample was taken and crushed using mortar and pestle. Chloroform solution and methanol (in 1:1 ratio) were added as the solvent. The brown seaweed extract thus obtained, was pasted using a capillary pipe to a silica gel plate (stationary phase) with gap of approximately $0.5-1 \mathrm{~cm}$ from the tip until a spot was detected. After the spot dried out, the silica gel plates were placed in the chamber containing hexane solution and ethyl acetate by ratio 7:3 (mobile phase). The movement of motion phase was observed until it was passed through the stationary phase to the limit of $\pm 10 \mathrm{~cm}$. The pigment examination was done visually using the UV transilluminator. The Racing Factor (Rf) value was calculated using the formula below:

$$
R f=\frac{\text { the distance travelled by the compound }}{\text { the distance travelled by the solvent }}
$$

The Rf value obtained from TLC was compared to the standard $\mathrm{Rf}$ value for estimating the brown seaweed pigments (Table 2).

\section{Sequence sources}

For phylogenetic relationships in silico analysis, DNA sequences of ribulose bisphosphate carboxylase large $(r b c \mathrm{~L})$ plastid genome of brown seaweeds were downloaded from the National Centre for Biotechnology Information (NCBI) nucleotide database (www.ncbi.nlm.nih.gov). The $r b c \mathrm{~L}$ brown seaweeds species and accession number were shown in Table 3.

\section{Sequence sources}

For phylogenetic relationships in silico analysis, DNA sequences of ribulose bisphosphate carboxylase large $(r b c \mathrm{~L})$ plastid genome of brown seaweeds were downloaded from the National Centre for Biotechnology Information (NCBI) nucleotide database (www.ncbi.nlm.nih.gov). The $r b c \mathrm{~L}$ brown seaweeds species and accession number were shown in Table 3.

Table 2. Pigments content assessment based on Rf value (Bhatia et al. 2015)

\begin{tabular}{lc}
\hline Pigment & Rf value \\
\hline Chlorophyll a & 0.68 \\
Chlorophyll b & 0.54 \\
Chlorophyll c & 0.03 \\
$\beta$-Carotene & 0.94 \\
Fucoxanthin & 0.51 \\
Lutein & 0.43 \\
Violaxanthin & 0.22 \\
Neoxanthin & 0.08 \\
\hline
\end{tabular}

Table 3. The rbcL brown seaweeds for phylogenetic relationships in silico analysis

\begin{tabular}{lc}
\hline Species & Accession number \\
\hline Cylindrocarpus rugosus & HQ990512 \\
Hydroclathrus clathratus & HQ990537 \\
Padina minor & KM598301 \\
Sargassum crassifolium & KP101271 \\
Sargassum cristaefolium & KP101275 \\
Sargassum hemiphyllum & KC782895 \\
Sargassum odontocarpum & KJ872543 \\
Sargassum oligocystum & KP096248 \\
Sargassum polycystum & KX254589 \\
Turbinaria conoides & DQ448834 \\
Turbinaria ornata & DQ448832 \\
\hline
\end{tabular}




\section{Data analysis}

Numerical phenetic relationship analysis

The phenetic relationships of brown seaweeds was analyzed quantitatively using the numerical taxonomy method. Morphological, anatomical, and biochemical characters data were scored, standardized, re-scored and converted into binary data. Using the binary data, clustering analysis was analyzed by the UPGMA method based on Gower similarity coefficient while ordination was performed based on the principal component analysis (PCA) method. Clustering and ordination were computed in MVSP 3.1.

\section{Phylogenetic relationships in silico analysis}

The eleven identified brown seaweed species were subjected to phylogenetic analysis. The sequences were written into multi-sequence FASTA files. All multiple sequences were aligned using ClustalW and phylogram reconstruction was performed using Neighbor-Joining (NJ) method in MEGA 7.0.

\section{RESULTS AND DISCUSSION}

\section{Numerical phenetic relationships}

Phenetics is a method of analyzing relationships based on similarities of phenetic characters such as morphological, anatomical, biochemical or other observable traits. The most widely used method to analyze the phenetic relationship is the numerical taxonomy or taxometrics. Numerical taxonomy aims to determine the phenetic relationship between organisms or taxa based on the similarity of all existing characters and such organisms or taxa undergoing such observation are referred to as Operational Taxonomic Units (OTUs) (Stuessy 2009). The present study examines 55 morphological, anatomical, and biochemical taxonomic characters (Table 4). Those characters were qualitative and quantitative in nature and included categorical, continuous, or binary character types.

Clustering pattern was calculated using the Gower coefficient association and the UPGMA (Unweighted Pair Group Method using Arithmetic Averages) method. The Gower coefficient was used for determining similarity between OTUs as it is reported to be more efficient to use on complex binary, multistate, and quantitative data (Stuessy 2009). The UPGMA phenogram can be observed in Figure 2.

Principal Component Analysis (PCA) is generally used to simplify data variables and reduce data dimension by converting them into new variables called principal components (Miranda et al. 2008). A scattered plot of the PCA result that presented the grouping of OTUs based on prominent characters can be seen in Figure 3 and the value of main component was shown in Table 5.

From Figure 3, we understand that the PCA analysis using the Euclidean biplot on morphological, anatomical, and biochemical characters resulted in cumulative percentage of $71.37 \%$ from two main components, indicating that $71.37 \%$ of 55 characters plays an important role in clustering pattern between OTUs. The principal component value on first axis (PC1) was $55.42 \%$, while the value on second axis (PC2) was $15.95 \%$, which showed that the value on first axis had higher contribution to the clustering patterns compared to second axis (Table 5).

Table 4. Taxonomic characters of brown seaweeds based on morphological, anatomical, and biochemical characters

\begin{tabular}{|c|c|}
\hline Character & Type of character \\
\hline General form thalli & Categorical \\
\hline Growth direction & Continuous \\
\hline Height of thalli & Continuous \\
\hline Thalli color & Categorical \\
\hline Substrate & Categorical \\
\hline Habitat & Categorical \\
\hline Position on shore (deep) & Categorical \\
\hline Blades shape & Categorical \\
\hline Length of blades & Continuous \\
\hline Width of blades & Continuous \\
\hline Position of blades & Categorical \\
\hline Blades tip & Categorical \\
\hline Margin & Categorical \\
\hline Midrib & Categorical \\
\hline Presence of air bladder & Binary \\
\hline Air bladder shape & Categorical \\
\hline Diameter of air bladder & Continuous \\
\hline Position of air bladder & Categorical \\
\hline Presence of crypto stomata & Binary \\
\hline Crypto stomata form & Categorical \\
\hline Position of crypto stomata & Categorical \\
\hline Number of crypto stomata & Categorical \\
\hline Presence of holdfast & Binary \\
\hline Holdfast shape & Categorical \\
\hline Presence of stipe/stalk & Binary \\
\hline Length of main axis & Continuous \\
\hline Main axis form & Categorical \\
\hline Main axis diameter & Continuous \\
\hline Type of branching & Categorical \\
\hline Spine on stalk & Binary \\
\hline Presence of phylloid & Binary \\
\hline Phylloid form & Categorical \\
\hline $\begin{array}{l}\text { Presence of fertile branchlets } \\
\text { (receptacle) }\end{array}$ & Binary \\
\hline Receptacle form & Categorical \\
\hline Growth system & Categorical \\
\hline Sexual reproduction & Binary \\
\hline Cell layer of main axis (stipe) & Binary \\
\hline Meristoderm shape & Binary \\
\hline Cortex shape & Binary \\
\hline Medulla shape & Binary \\
\hline Cell layer of blades & Binary \\
\hline Meristoderm shape & Binary \\
\hline Cortex shape & Binary \\
\hline Medulla shape & Binary \\
\hline Cell layer of air bladders & Binary \\
\hline Meristoderm shape & Binary \\
\hline Cortex shape & Binary \\
\hline Cell color & Categorical \\
\hline Chlorophyll a & Binary \\
\hline Chlorophyll c & Binary \\
\hline$\beta$-Carotene & Binary \\
\hline Lutein & Binary \\
\hline Violaxanthin & Binary \\
\hline Fucoxanthin & Binary \\
\hline Neoxanthin & Binary \\
\hline
\end{tabular}


Table 5. The principal components of morphological, anatomical, and biochemical characters values of brown seaweeds

\begin{tabular}{lll}
\hline Characters & Axis 1 & Axis 2 \\
\hline General form thalli & $\mathbf{0 . 4 0 3}$ & -0.001 \\
Growth direction & $\mathbf{0 . 4 1 1}$ & 0 \\
Height of thalli & $\mathbf{0 . 1 9 1}$ & $\mathbf{- 0 . 2 4 5}$ \\
Thalli color & 0.05 & $\mathbf{0 . 3 6 3}$ \\
Substrate & $\mathbf{0 . 4 1 1}$ & 0 \\
Position on shore (deep) & 0.042 & $\mathbf{0 . 2 5 4}$ \\
Blades shape & $\mathbf{0 . 1 2}$ & $\mathbf{0 . 3 7 3}$ \\
Length of blades & 0.025 & $\mathbf{0 . 1 2 7}$ \\
Width of blades & 0.025 & $\mathbf{0 . 1 2 7}$ \\
Position of blades & $\mathbf{0 . 2 0 3}$ & $\mathbf{0 . 4 8 6}$ \\
Blades tip & $\mathbf{0 . 2 5 4}$ & -0.076 \\
Margin & $\mathbf{0 , 1 9 7}$ & $\mathbf{- 0 , 1 3 5}$ \\
Midrib & 0.054 & -0.053 \\
Air bladder shape & $\mathbf{0 . 2 4 9}$ & $\mathbf{- 0 . 2 5 8}$ \\
Crypto stomata form & $\mathbf{0 . 2 4 9}$ & 0.064 \\
Position of crypto stomata & 0.085 & -0.069 \\
Holdfast shape & $\mathbf{0 . 3 0 1}$ & -0.059 \\
Length of main axis & $\mathbf{0 . 1 9 5}$ & $\mathbf{- 0 . 2 0 6}$ \\
Main axis form & 0.058 & -0.014 \\
Type of branching & 0.094 & $\mathbf{- 0 . 1 2 9}$ \\
Phylloid form & $\mathbf{0 . 1 3 7}$ & $\mathbf{0 . 1 3 1}$ \\
Receptacle form & 0.045 & 0.074 \\
Growth system & 0.025 & $\mathbf{0 . 1 2 7}$ \\
Cell color & 0.05 & $\mathbf{0 . 3 6 3}$ \\
\hline
\end{tabular}

The characters with high component values on axis 1 (more than 0.1 or less than -0.1 ) have a role in clustering between OTUs as stated by Chahal et al. (2002), the greater the value of the main component on the first axis, the greater the effect of this character in grouping or clustering.

\section{Phylogenetic relationships analysis}

The reconstruction of phylogram was done by the NJ grouping method. This method is one of the most commonly applied distance-based methods and it uses evolutionary distance data to reconstruct phylogenetic trees. NJ gives the assumption that each OTUs has different evolutionary rate. The principle of NJ is to find OTUs or neighbors that minimize the total branch length (Baxevanis and Oullette 2005). The result of the phylogram reconstruction using the NJ method was shown in Figure 4.

\section{Discussion \\ Numerical phenetic relationships}

Based on Figure 2, Sargassum crassifolium and $S$. cristaefolium had the highest similarity value (0.982) and were closely clustered. $S$. cristaefolium is the synonym of S. duplicatum J. Agardh because it is considered a "duplicate" of $S$. crassifolium. In general, the morphological appearance of these two species looks similar. The striking difference between them is located in its blades margin morphology. S. cristaefolium has thick margins and is double-edged and each edge pointed in a different direction. These double edges itself usually found on the blade located in the base near its lateral branch (Ang and Trono 1987). Turbinaria conoides and T. ornata have a relatively high similarity value $(0.964)$ due to their usual characteristic of Turbinaria which is turbinate-shaped thalli. $T$. conoides and $T$. ornata only differ in the shape of the blade. While, T. conoides have a reinformed blade with a serrated margin and have air bladder which protrudes from the middle of the blade, $T$. ornata blade is conical with serrated margin and the inside of the blade is warped inward. Moreover, T. ornata has an intramarginal crown with rough serration that surrounds the middle cavity of the blade and the air bladder of a $T$. ornata is relatively 'sunken' in the middle of the blade (Rohfritsch et al. 2007).

The UPGMA phenogram (Figure 2) forms two clusters (Figure 2). The OTUs belong to the Fucales grouped into cluster I, while others were grouped into cluster II. Cluster $\mathrm{I}$ is divided into sub-clusters Ia and Ib. Subcluster Ia is a group of Sargassum spp. except for S. hemiphyllum. S. hemiphyllum grouped with the Turbinaria in the subcluster Ib. S. hemiphyllum was clustered near Turbinaria due to resemblance of blade shape of S. hemiphyllum to that of Turbinaria, which is serrated at the top with a flattened and thick blade.

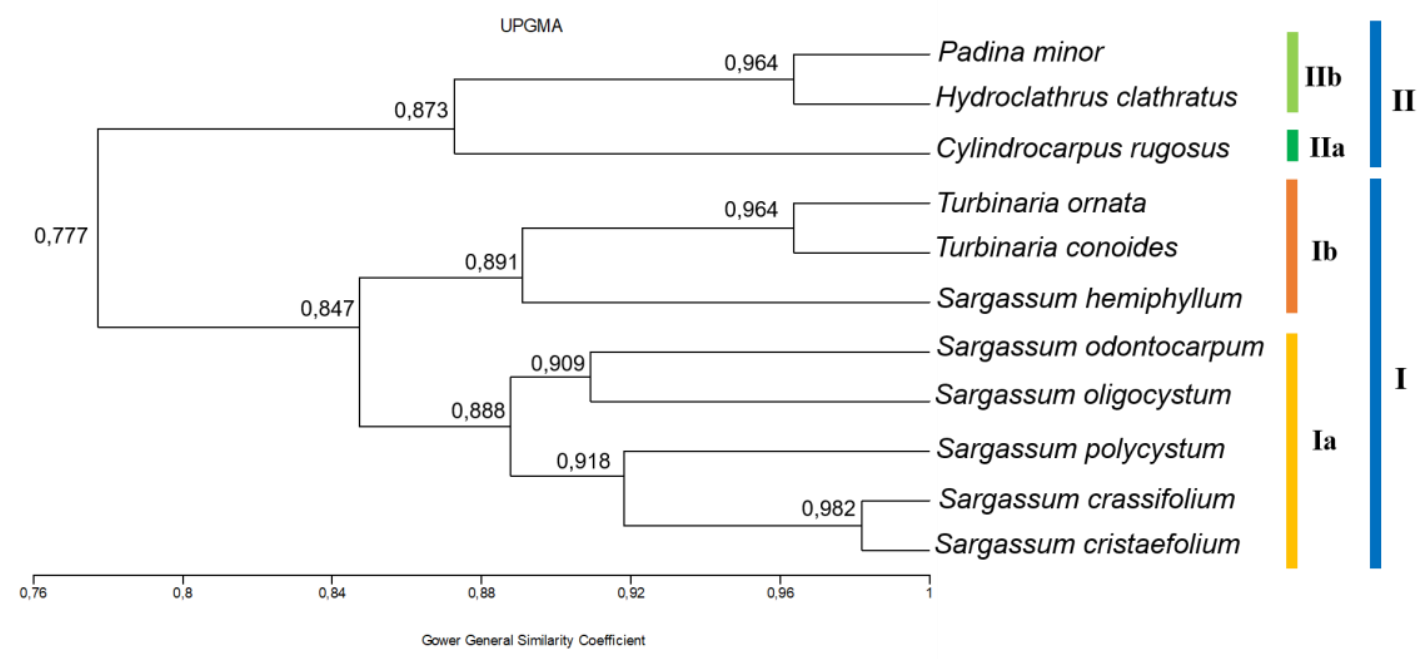

Figure 2. The UPGMA phenogram of brown seaweeds from Gunungkidul, Yogyakarta, Indonesia 


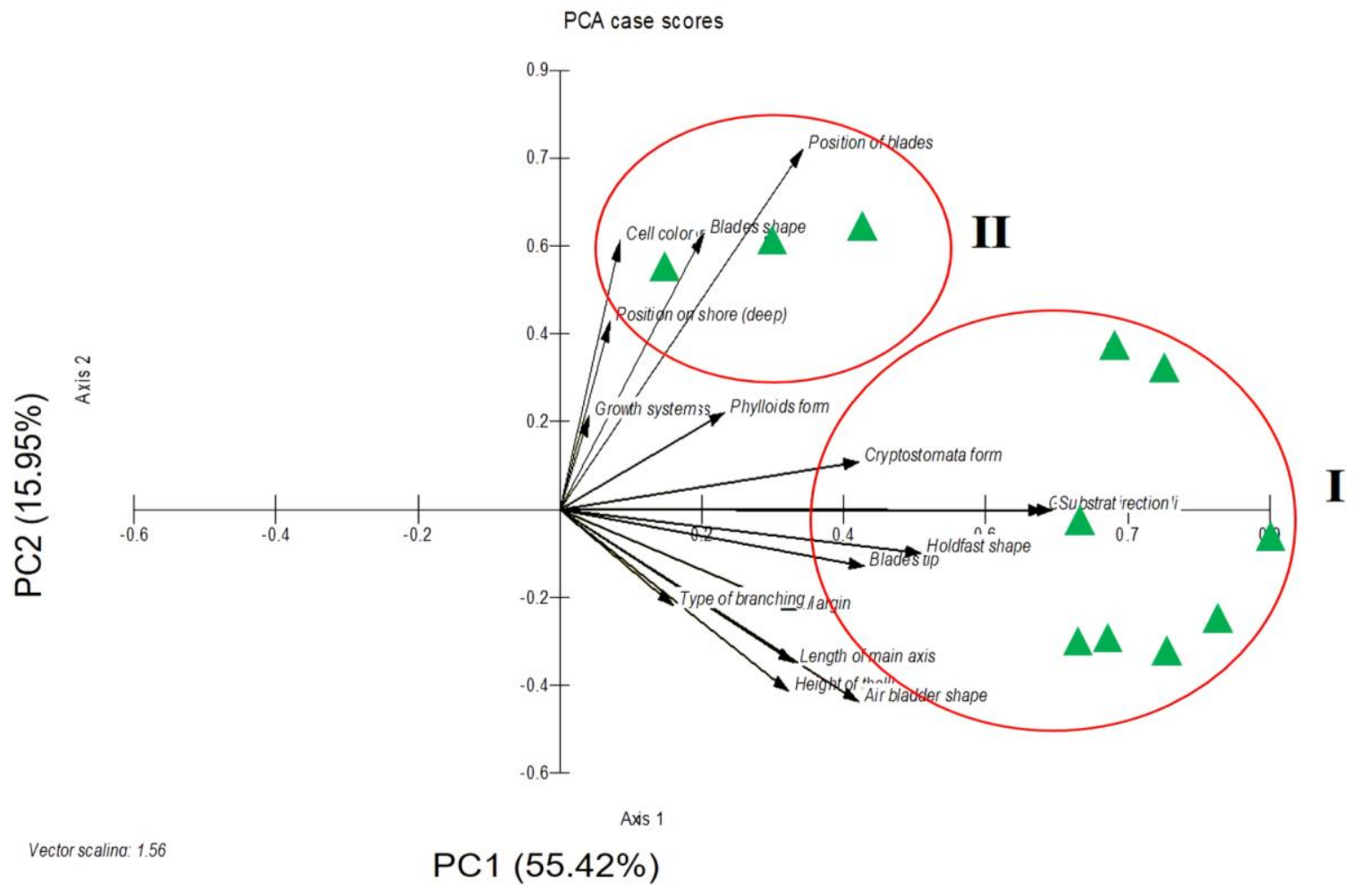

Figure 3. Scattered plot of the PCA of brown seaweeds based on morphological, anatomical, and biochemical characters with the cumulative percentage of first and second components were 71.37\% (PC1 55.42\% and PC2 15.95\%).

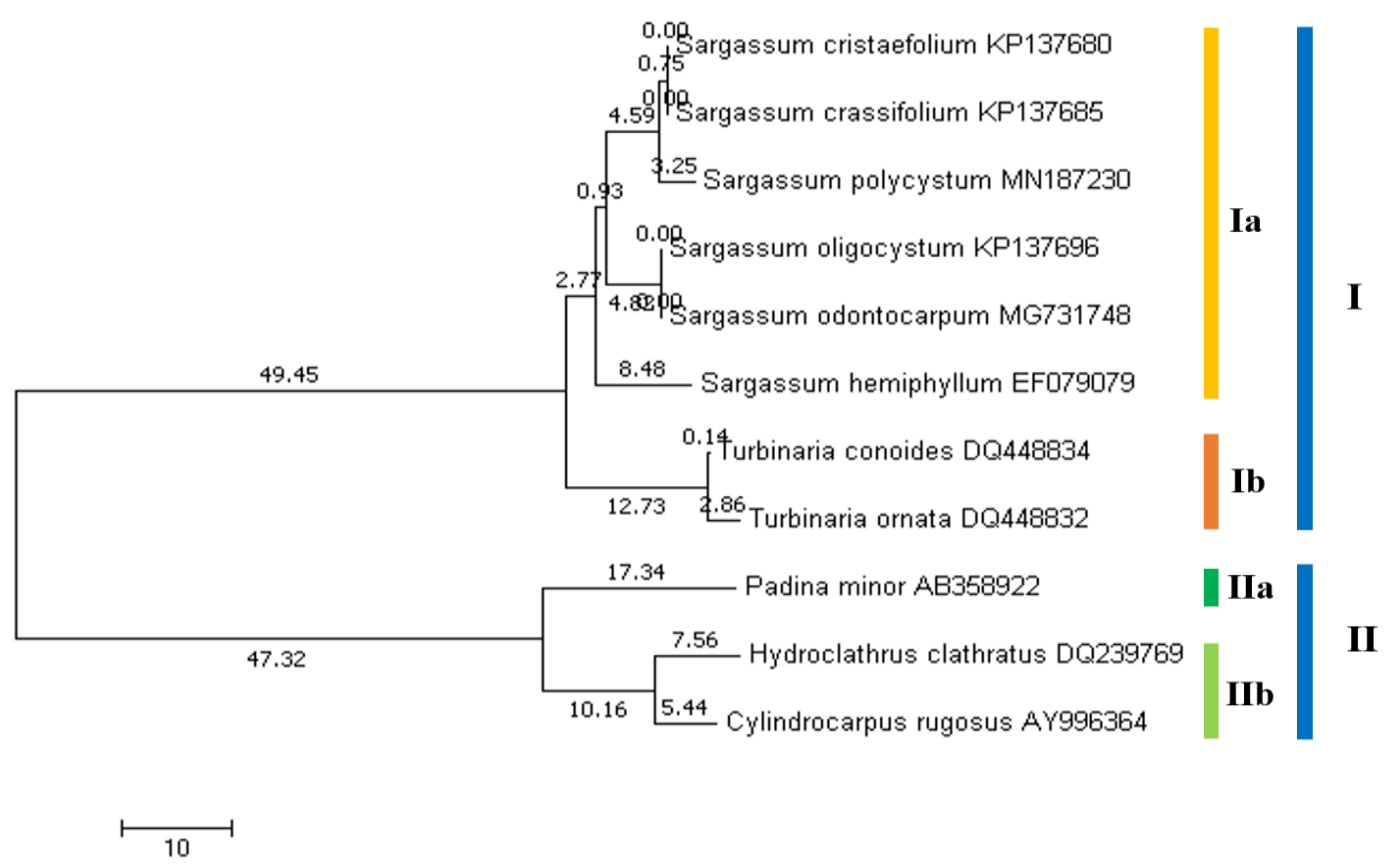

Figure 4. The NJ phylogram of brown seaweeds from Gunungkidul Yogyakarta Indonesia

In Figure 3, the scattered-plot PCA forms two clusters. Cluster I consist of Fucales members and Cluster II had members of Dictyotales and Ectocarpales. Each character determined its effect in forming clusters between OTUs. In
Table 5, the characters of the general form of the thalli, the direction of growth of the thalli, and the substrate are the characters with the highest component values. It was also shown in Figure 2, that three characters had the longest 
Euclidean distance leading to cluster I. These three characters distinguishing Hydroclathrus, Cylindrocarpus, and Padina, which have an irregular thallus with many perforated holes, a cushion-like shape, and a fan-like shape respectively; the direction of growth is spread and pulvinate; with a variety of substrates, some are free-living such as Hydroclathrus, attached to corals reefs such as Cylindrocarpus and sandy substrate such as Padina. In cluster II, the blade position had the highest value and was plotted in PCA with a longer line leading to cluster II. Blade positions on C. rugosus, $H$. clathratus, and $P$. minor were on the upper surface, while Sargassum and Turbinaria were dense to form cylindrical, solid in the main branch, or clustered in Turbinaria.

Based on Table 5, we obtained the component values of more than 0.1 or less than -0.1 on both axes. These characters include the height of the thalli, the shape of the blade, the length of the main axis, the shape of the air bladder, and the shape of the phylloid. These characters were deducted as characters that play a role in separation between cluster I and cluster II due to the Sargassum and Turbinaria thalii was far higher than Hydroclathrus, Cylindrocarpus, and Padina. The thalli of Sargassum and Turbinaria ranges from $30-50 \mathrm{~cm}$ while Hydroclathrus, Cylindrocarpus, and Padina varied between $2-8 \mathrm{~cm}$. The blade of Sargassum is foliose form, Turbinaria is turbinate, Cylindrocarpus is convoluted-rugose, Hydroclathrus is irregular with perforations, and Padina is fan-shaped. Furthermore, cluster I members have air bladder with various shapes while cluster II does not have an air bladder. Additionally, the phylloid are only found in Fucales (Sargassum and Turbinaria) with various forms.

Based on the value of each component generated from the PCA analysis, it can be assumed that the higher the value of the character, the greater the character will affect the clustering between OTUs. The value of principal component for each character shows that morphological characters showed more variations than the anatomical and biochemical characters. The morphology is the main feature that is used in the classical botanical taxonomy, due to convenience. Every specific taxon has a set of morphological traits. Morphology of thalli, blade shape, blade margin shape, air bladder, and the shape of holdfast could be character traits of brown seaweeds. Hence, the morphological characters are the easiest data to observe and analyze for numerical phenetic analysis.

\section{Phylogenetic relationship analysis}

Phylogenetic relationships in silico is an approach method to determine the relationship of the organisms based on their evolutionary relationships through computer simulations. In silico analysis using bioinformatics and the availability of database information (DNA, RNA, protein, etc.) which can be accessed openly on an online site. One of the genetic materials used for phylogenetic analysis is the $r b c \mathrm{~L}$ gene found in plastids. The $r b c \mathrm{~L}$ gene is widely used for species identification in plants and organisms with chloroplast because it shows a high mutation rate (Purty and Chatterjee 2016).
Based on the reconstruction of NJ phylogram (Figure 4), two clusters and two sub-clusters each were formed. Cluster I consist of Fucales, further divided into sub-cluster Ia (Sargassum spp.) and sub-cluster Ib (Turbinaria spp.). This close cluster indicated that Sargassum and Turbinaria are monophyletic and originated from the same ancestor. Within sub-cluster I, S. crassifolium and S. cristaefolium were closely related (or might be similar species) compared to other species as indicated by the branching distance value of 0.0. Further, the NJ phylogram also described the changes that occurred in the marker genes for each species. The longer branch meant the more changes in the marker genes during the evolutionary process, so that the species on that branch could be more advanced. The Dictyotales and Ectocarpales were clustered in sub-cluster II, separated to sub-cluster IIa (Dictyotales) and sub-cluster IIb (Ectocarpales), which indicated that Dictyotales be closely related to Ectocarpales and assumed to be monophyletic.

Specifically, the phenogram (Figure 2) of the numerical phenetic analysis showed that the S. hemiphyllum were grouped near Turbinaria and Padina minor was grouped near Hydroclathrus clathratus. Conversely, phylogram of the phylogenetic analysis (Figure 4) unveil that $S$. hemiphyllum was grouped with other species belonging to the Sargassum and $H$. clathratus grouped near Cylindrocarpus rugosus as both belong to the order Ectocarpales, while Padina minor (Dictyotales) formed its own sub-cluster. The phylogenetic relationships analysis in silico using the $r b c \mathrm{~L}$ gene showed that there were close relationships between the Dictyotales, Ectocarpales, and Fucales.

In conclusion, our study reveals that relationships analysis among brown seaweeds from Gunungkidul Yogyakarta Indonesia based on numerical phenetic and phylogenetic relationships in silico both forming two clusters even though the species that compose the subcluster were slightly different. The characteristics that play an important role in grouping brown seaweeds consist of the length of thalli, the shape of the blade, the length of the main axis, the shape of the air bladder, and the shape of the phylloid.

\section{ACKNOWLEDGEMENTS}

This study was supported by RTA UGM Grant 2020 2488/UNI.P.III/DIT.LIT/PT/2020. Special thanks to Dwi Sartika, Septi Lutfiatun Nafiah, and Septy Wulan Cahyani, who helped a lot during this study, whether in field or laboratory. We also want to express our gratitude toward Plant Systematics Laboratory, Faculty of Biology, Universitas Gadjah Mada, Yogyakarta, Indonesia.

\section{REFERENCES}

Abbott IA, Dawson EY. 1978. How to Know the Seaweeds, Second Edition. Wm. C. Brown Company, Dubuque, Iowa.

Ang Jr.PO, Trono Jr.GC. 1987. The Genus Sargassum (Phaeophyta, Sargassaceae) from Balibago, Calatagan, Philippines. Botanica Marina 30 (5): 387-397. DOI: 10.1515/botm.1987.30.5.387 
Baxevanis AD, Oullette BFF (eds). 2005. Bioinformatics: A Practical Guide to the Analysis of Genes and Proteins (3rd Edition). Wiley, United States.

Bhatia S, Nagpal K, Bera T, Sharma A, Sharma K. 2015. Evaluation of pharmacognostical, phytochemical and anti-microbial properties of Porphyra vietnamensis. Intl J Green Pharm 9 (1): 131-137. DOI: 10.4103/0973-8258.155065

Chahal GS, Gosal SS. 2002. Principles and Procedures of Plant Breeding: Biotechnological and Conventional Approaches. Alpha Science International, Oxford, UK.

Chasani AR, Suyono EA. 2020. Comparison of structure and composition of seaweeds population in Porok and Greweng Coasts, Gunungkidul, Indonesia. AIP Conf Proc 2260: 020011. DOI: 10.1063/5.0016133.

Dawes CJ. 1998. Marine Botany, $2^{\text {nd }}$ ed. John Wiley \& Sons Inc, New York.

Dawson, E.Y. 1954. Marine plants in the vicinity of the Institute Oceanography of Nha Trang. Pac Sci 8: 373-471.

Draisma SGA, Prud'homme van Reine WF, Stam WT, Olsen JL. 2001. A Reassessment of Phylogenetic Relationships within the Phaeophyceae based on RUBISCO large subunit and Ribosomal DNA Sequences. J Phycol 37: 586-603. DOI; 10.1046/j.1529-8817.2001.037004586.x

Kadi A. 2005. Beberapa catatan kehadiran marga Sargassum di perairan Indonesia. Oseana 30 (4): 19-29. [Indonesian]

Karleskint G, Turner R, Small J. 2010. Introduction to Marine Biology, Third Edition. Brooks/Cole Cengage Learning, Belmont, CA.

Littler DS, Littler MM. 2003. South Pacific Reef Plants: A Drivers' Guide to The Plant Life of South Pacific Coral Reefs. OffShore Graphics Inc, Washington, D.C.
Miranda AA, Le Borgne YA, Bontempi G. 2008. New Routes from Minimal Approximation Error to Principal Components. Neural Process Lett 27: 197-207. DOI: 10.1007/s11063-007-9069-2

Purty RS, Chatterjee S. 2016. DNA Barcoding: An Effective Technique in Molecular Taxonomy. Austin J Biotechnol Bioeng 3 (1): 1059.

Readdie MD, Ranelletti M, McCourt RM. 2006. Common Seaweeds of the Gulf of California. Sea Challangers, Inc., Monterey, CA.

Rohfritsch A, Payri C, Stiger V, Bonhomme F. 2007. Molecular and morphological relationships between two closely related species, Turbinaria ornata and T. conoides (Sargassaceae, Phaeophyceae). Biochem Syst Ecol 35: 91-98. DOI: 10.1016/j.bse.2006.09.002.

Sahoo D, Seckback J (eds.). 2015. The Algae World. In Series: Cellular Origin, Life in Extreme Habitats and Astrobiology. Springer Science+Business Media, Dordrecht. DOI: 10.1007/978-94-0177321-8

Silberfeld T, Rousseau F, de Reviers B. 2014. An Updated Classification of Brown Algae (Ochrophyta, Phaeophyceae). Cryptogam Algol 35 (2): 117-156. DOI: 10.7872/crya.v35.iss2.2014.117

Smith GM. 1951. Manual of Phycology - An Introduction to the Algae and Their Biology. Chronica Botanica Co, Waltham.

Soltis PS, Soltis DE, Doyle JJ. 2012. Molecular Systematics of Plants. Springer Science+Business Media, Dordrecht.

Stuessy TF. 2009. Plant taxonomy: the systematic evaluation of comparative data, $2^{\text {nd }}$ ed. In: Stuessy TF (eds). Systematic Biology. Columbia University Press, New York. DOI: 10.1093/sysbio/syq017

Zhang J, Wang X, Liu C, Jin Y, Liu T. 2013. The complete mitochondrial genomes of two brown algae (Laminariales, Phaeophyceae) and phylogenetic analysis within Laminaria. J Appl Phycol 25: 12471253. DOI: 10.1007/s10811-012-9915-0. 